\title{
Reckoning of antioxidant and antiobesity potential of Anethum sowa L. roots extract in experimental rodent model
}

\author{
Sangeeta Singh, Muhammad Arif^, Tarique Mahmood, Farogh Ahsan, Mohammad Shariq and Mohammad Khalid
} Faculty of Pharmacy, Integral University, Kursi Road, Lucknow-226026, Uttar Pradesh, India

\begin{tabular}{|c|c|}
\hline Article Info & Abstract \\
\hline $\begin{array}{l}\text { Article history } \\
\text { Received } 25 \text { August } 2021 \\
\text { Revised } 11 \text { October } 2021 \\
\text { Accepted } 12 \text { October } 2021 \\
\text { Published Online } 30 \text { December } 2021\end{array}$ & $\begin{array}{l}\text { Anethum sowa L. (Family: Umbelliferae) is a traditional herb, containing phenolic compounds and } \\
\text { flavonoids having curative value. The total phenolics and flavonoid contents, antioxidant activity (in } \\
\text { vitro), and antiobesity activity of the ethanolic extract of Anethum sowa roots (EASR) through high-fat } \\
\text { diet induced antiobesity model in female SD rats were determined. The antioxidant activity was performed } \\
\text { using standard procedure of } 1,1 \text {-diphenyl-2picrylhydrazyl. Obesity was induced in female SD rats (in vivo) }\end{array}$ \\
\hline $\begin{array}{l}\text { Keywords } \\
\text { Anethum sowa L. } \\
\text { Antiobesity model } \\
\text { High-fat diet } \\
\text { Oxidative stress }\end{array}$ & $\begin{array}{l}\text { administration of (EASR) at dosage levels of } 100 \text { and } 200 \mathrm{mg} / \mathrm{kg} / \text { of body weight. During the study, } \\
\text { physical parameters like body weight, food intake, food efficiency ratio, BMI, relative organ weight and } \\
\text { lipid serum profile like total cholesterol (TC), total triglycerides (TG), low density lipoprotein (LDL), very } \\
\text { low-density lipoprotein (VLDL), high-density lipoprotein (HDL), and atherogenic index (AI) were } \\
\text { determined. Various oxidative stress markers such as superoxide dismutase (SOD), glutathione (GSH), } \\
\text { glutathione peroxidase (GP) and thiobarbituric acid reactive substances (TBARS) were also measured. } \\
\text { The present research exhibited that A. sowa roots exerted notable free radicals scavenging potentiality. } \\
\text { Feeding high fat diet resulted in marked increase in the body weight, TC, TG, LDL and VLDL levels and a } \\
\text { reduction in the HDL level. Treatment with EASR at dose } 100 \text { and } 200 \mathrm{mg} / \mathrm{kg} / \text { body weight showed } \\
\text { significant (P: }{ }^{*} p<0.05 \text { and } * * p<0.01 \text { ) antiobesity effects. The present data exhibited that ethanolic } \\
\text { extract of } A . \text { sowa roots exerted notable antiobesity potentiality. }\end{array}$ \\
\hline
\end{tabular}

\section{Introduction}

Obesity is one of the long-standing disorders with several diverse aetiology including genetics, environment, metabolism, lifestyle, and behavioural components. Factors such as proper nourishment, right eating habits and physical activity plays a significant role in controlling obesity (Wichtl, 1994). Obesity is abnormal accumulation of body fat which may have negative effect on health. Body Mass Index (BMI) is commonly used to determine a person's obesity. Not only the urban population of India is facing high rates of obesity due to their sedentary lifestyle, even the rural population is not resistant because of the use of modern technology in most of the farming occupations and less physical activity (Blumenthal et al., 2000). WHO determined obesity as global epidemic. The latest study conducted in 2005 by WHO indicates that approximately 1.6 billion adults were overweight and about 400 million adults were obese (Giampiero et al., 2002; Suresha, 2004). Several disorders are originated or made worse by obesity. These involve type-2 diabetes; hypertension; dyslipidaemia; ischemic heart disease; stroke; obstructive sleep apnoea; asthma; non-alcoholic steatohepatitis; gastroesophageal reflux disease; degenerative joint

Corresponding author: Dr. Muhammad Arif Associate Professor, Faculty of Pharmacy, Integral University, Kursi Road, Lucknow-226026, Uttar Pradesh, India

E-mail: arifxyz@iul.ac.in

Tel.: +91-9918464963

Copyright () 2021 Ukaaz Publications. All rights reserved.

Email: ukaaz@yahoo.com; Website: www.ukaazpublications.com disease of the back, hips, knees, and feet; infertility and polycystic ovary syndrome; various malignancies; and depression (Cordatos et al., 1992).

The Indian dill plant, A. sowa often known as dill is an annual odoriferous herb, belonging to family Umbelliferae (Singh and Panda, 2005). Dill plant has an extensive past of cultivation and utilized as culinary and therapeutic herb. The herb is cultivated throughout India, mainly in Punjab, Uttar Pradesh, Gujarat, Maharashtra, Assam and West Bengal (Randhawa et al., 1995). A. sowa provides relief to digestive problems and stimulates milk to feeding mothers. It also possesses antimicrobial, antifungal, antioxidant, insecticidal, anti-inflammatory, antispasmodic, antidiabetic, anticancer and antihypercholesterolaemia, due to the existence of therapeutically active compounds (Chahal et al., 2017). There are several chemically synthesized drugs are available in market for obese patients but they have significant adverse drug reactions and is not appropriate for old age patients. So, it is necessary to develop drugs which are safe for the treatment of obesity, and traditional systems of therapy provide the path for the same.

\section{Materials and Methods}

\subsection{Collection and certification of plant}

The roots of $A$. sowa were collected from our kitchen garden Paikramau, Lucknow in November 2018. The plant specimen was authenticated from "CSIR-National Botanical Research Institute" Lucknow with Voucher Specimen ref. No: NBRI/CIF/668/2018. 


\subsection{Chemicals and drugs}

Triglycerides (TG) kit, total cholesterol (TC) kit low-density lipoprotein (LDL) kit and high-density lipoprotein (HDL) kit were purchased from Agappe Diagnostics Ltd., Kerela, India. All the other chemicals used including the solvents, were of analytical grade procured from SD Fine Chemicals Limited and Fischer Scientific Ltd. The standard drug Orlistat has been approved by the US Food and Drug Administration (FDA) precisely for obesity (Kaur and Kulkarni, 2000). This drug was procured from Quantum In. 64 C, Khasra 133 Narayan Nagar, Virat Khand Rd, Kamta, Lucknow, Uttar Pradesh 226028.

\subsection{Extract preparation}

Roots were collected from our kitchen garden, thoroughly wash with tap water and shade dried at room temperature for 4 weeks to get a consistent weight and grinded to obtain coarse powder. $50 \mathrm{~g}$ of powdered root was extracted with $250 \mathrm{ml}$ of ethanol using Soxhlet apparatus. The extraction was carried out until the solvent became clear. The filtrate was concentrated to dryness under reduced pressure at $40^{\circ} \mathrm{C}$ through rotary evaporator (Sachan et al., 2011). The yield of ethanol extract was $3.7 \%$ w/w. To check the primary and secondary metabolites in the ethanolic extract of $A$. sowa roots (EASR) were performed by the qualitative preliminary phytochemical screening (Arif and Fareed, 2010; Modi et al., 2018).

\subsection{Animals}

Thirty female Sprague Dawley (SD) rats (142-158 g) were obtained from CDRI (Lucknow, Uttar Pradesh) and maintained in standard laboratory conditions (temperature $20-25^{\circ} \mathrm{C}$, humidity $50 \pm 15 \%$ and $12 \mathrm{~h}$ each of dark and light periods). Rats were provided with commercial pellet diet and water ad libitum. Acclimatisation of rats with the laboratory environment was done for one week before the initiation of the experiment. Experimental procedures were carried out in accordance with the guidelines of Institutional Animal Ethics Committee (Approval Number: IU/IAEC/19/13).

\subsection{Experimental schedule}

After one week of acclimatisation, obesity was induced by randomly allotting the animals into normal and obese groups and fed with normal pellet diet (NPD) and high-fat diet (HFD) and ad libitum, respectively for one week (Srinivasan et al., 2005). The composition of HFD (Harlan Teklad TD93075) in \% kcal is contains carbohydrates $(24.0 \%)$, protein $(21.2 \%)$ and fat $(54.8 \%)$ and component of each mentioned in Table 1.

The rats were divided in to 5 groups of 6 rats in each $(n=6)$ for study. In the diet induced antiobesity model, normal control group (I) was fed with normal pellet diet and received normal saline, group (II) was fed with high-fat diet, groups (III and IV) received the 100 and $200 \mathrm{mg} / \mathrm{kg} /$ day of ethanolic extract of $A$. sowa roots (EASR), and (group V) was treated with standard drug Orlistat (5 $\mathrm{mg} / \mathrm{kg}$ ). All groups except normal control group (I) was fed with high fat-diet for 10 days, then groups (III, IV and V) were treated test drugs for 28 days along with HFD, respectively. On $29^{\text {th }}$ day, the rats were measured, weighed and sacrificed with diethyl ether for the evaluation of physical parameters, lipid serum profile and oxidative stress (Vijaya et al., 2011).

Table 1: High fat diet (HFD) composition

\begin{tabular}{|l|c|l|}
\hline Formula & $\mathbf{g} / \mathbf{k g}$ & Representative components \\
\hline Casein & 289.0 & Ground corn \\
DL-methionine & 3.33 & Dehulled soybean meal \\
Corn starch & 207.3 & Ground oats \\
Sucrose & 90.5 & Wheat middlings \\
Vegetable shortening, hydrogenated & 274.1 & Dehydrated alfalfa meal \\
Corn oil & 16.0 & Soybean oil \\
Cellulose & 53.12 & Corn gluten meal \\
Vitamin mix, teklad (40060) & 13.33 & Iodized salt \\
Mineral mix, AIN-76 (170915) & 46.66 & Brewers dried yeast \\
Calcium carbonate & 6.66 & Calcium carbonate \\
\hline
\end{tabular}

\subsubsection{Evaluation of physical parameters}

The body weight $(\mathrm{g})$, food intake $(\mathrm{g})$ and food efficiency ratio were documented once in a week for 28 days of each group (Ordonez et al., 2006). Body Mass Index (BMI) of animals was calculated by measuring the weighed and length (Nasal to anal length) every week using electronic balance and ruler. To calculate BMI of rats following formula was used:

$$
\frac{\text { Body weight }(\mathrm{gm})}{\operatorname{Length}^{2}\left(\mathrm{~cm}^{2}\right)}
$$

The relative organ weight of liver, kidneys, spleen, heart, lungs and brain to body was determined. The organs were deliberately dissected out and weighed. These organs were stored in $10 \%$ neutral buffered formalin. The relative organ to body weight was calculated using the following formula (Vani and Reddy, 2000).

Relative organ to body weight:

$$
=\frac{\text { Actual weight of the organ }(\mathrm{g})}{\text { Body weight of an individual rat on day of sacrifice }(\mathrm{g})}
$$




\subsubsection{Assessment of lipid serum profile}

On $29^{\text {th }}$ day, the blood was collected by retro orbital puncture method using diethyl ether and serum was separated using centrifugation. Then, the biochemical parameters such as cholesterol, TG, HDL, LDL, VLDL and atherogenic index were determined.

$$
\begin{aligned}
& \text { VLDL }-\mathrm{C} \text { levels }\left(\frac{\mathrm{mg}}{\mathrm{dl}}\right)=\text { Triglyceride level } / 5 \\
& \mathrm{LDL}-\mathrm{C} \text { level }\left(\frac{\mathrm{mg}}{\mathrm{dl}}\right)=\text { Total cholesterol } \\
& -(\mathrm{HDL}-\mathrm{C}+\mathrm{VLDL}-\mathrm{C}) \\
& \text { Atherogenic index }=(\mathrm{TC}-\mathrm{HDL}-\mathrm{C}) / \mathrm{HDL}-\mathrm{C}
\end{aligned}
$$

The levels of serum Very Low-Density Lipoprotein (VLDL) were calculated in accordance with a formula as described by Friedewald and Fredrickson (Friedewald et al., 1972: Nwagha et al., 2010).

\subsubsection{Parameters for oxidative stress}

\subsubsection{Effects of EASR on superoxide dismutase (SOD)}

The superoxide dismutase (SOD) activity was spectrophoto metrically determined by method developed by Marklund and Marklund (Kumar et al., 2009). SOD activity was revealed based on its ability to impede superoxide-mediated non-acceptance. One unit of SOD activity was defined as the amount of enzyme that inhibited the oxidation of pyrogallol by $50 \%$ and was expressed as unit/g $\mathrm{Hb}$ and that from the tissue as unit/mg protein.

\subsubsection{Effects of EASR on reduced glutathione (GSH)}

The procedure is based on the depletion of 5, 5 di-thiobis (2nitrobenzoic acid) (DTNB) with reduced glutathione (GSH) to give rise a yellow compound. The reduced chromogen is proportionate to GSH concentration and its absorbance can be estimated at 405 nm (Jaishree et al., 2010).

\subsubsection{Effects of EASR on glutathione peroxidase (GPx)}

$\mathrm{NADPH}$, i.e., oxidation substrate was estimated at $340 \mathrm{~nm}$. The activity of GPx was measured as quantity of NADPH oxidised per min per $\mathrm{mg}$ protein. The estimation of glutathione peroxidise activity was done by Mohandas et al. method (Janardanan et al., 1984).

\subsubsection{Effects of EASR on thiobarbituric acid reactive substances (TBARS)}

The results were measured as $\mathrm{nM}$ of TBARS formed per min per $\mathrm{mg}$. Absorbance was taken at $535 \mathrm{~nm}$ and the determination of lipid peroxidation was done according to the method of Iqbal et al. (2017).

\subsubsection{In vitro antioxidant activity}

\subsubsection{Estimation of total phenolic content in EASR}

Modified folin ciocalteu method was used to estimate the total phenolic content of the ethanolic extract of $A$. sowa roots (EASR) (Gezici et al., 2020). In a $25 \mathrm{ml}$ volumetric flask $(1 \mathrm{ml})$ of extract $(50,100$ and $200 \mathrm{mg} / \mathrm{ml})$ was diluted in distilled water $(9 \mathrm{ml})$ and added $1 \mathrm{ml}$ of Folin Ciocalteu reagent with stirring. After $5 \mathrm{~min}, 3$ $\mathrm{ml}$ sodium carbonate was added and made up the volume $25 \mathrm{ml}$. A reagent blank using distilled water was prepared and all samples were allowed to stand in dark for $1 \mathrm{~h}$. Absorbance was measured at $765 \mathrm{~nm}$ using UV spectrophotometer. The equation based on the calibration curve: $y=0.002 x, R^{2}=0.994$, was used to calculate the total phenolic content, where $\mathrm{x}$ was the absorbance and $\mathrm{y}$ was the gallic acid equivalent $(\mu \mathrm{g} / \mathrm{g})$.

\subsubsection{Estimation of total flavonoid content in EASR}

Aluminium-chloride colourimetric assay method was used to determine the total flavonoidal content (Muhammad and Sheeba, 2011). In a $10 \mathrm{ml}$ volumetric flask (1 ml) of extract (50,100 and 200 $\mathrm{mg} / \mathrm{ml})$ was diluted in distilled water $(4 \mathrm{ml})$ and mixed with $0.3 \mathrm{ml}$ of $5 \%$ sodium nitrite and after $5 \mathrm{~min}$, add $0.3 \mathrm{ml}$ of $10 \%$ aluminium chloride added. At the $6^{\text {th }}$ min add $2 \mathrm{ml} 1 \mathrm{M}-\mathrm{NaOH}$ and made up the volume $10 \mathrm{ml}$ with distilled water. Then, the mixtures were allowed to stand at room temperature for $30 \mathrm{~min}$ at room temperature and the absorbance was measured at $520 \mathrm{~nm}$. Total flavonoid content was calculated using the equation based on the calibration curve: $y$ $=0.001 \mathrm{xs}, \mathrm{R}^{2}=0.991$, where $\mathrm{x}$ was the absorbance and $\mathrm{y}$ was the rutin equivalent $(\mu \mathrm{g} / \mathrm{g})$.

\subsubsection{Free radical scavenging activity of EASR by DPPH method}

The DPPH assay is established on the quantification of the scavenging potentiality of an antioxidant using the stable 1,1diphenyl-2-picrylhydrazyl (DPPH) free radical (Wali et al., 2019). The colour of free radical DPPH is purple in ethyl alcohol and is reduced to the equivalent hydrazine, as it reacts with a hydrogen donor, which is yellow in colour. It is a discoloration assay, which is determined by the addition of the antioxidant to a DPPH solution in ethyl alcohol and the decrease in absorbance is established at 490 $\mathrm{nm}$ and calculated by using the following formula (Qadir et al., 2020).

$$
\% \text { Inhibition }=[(\mathrm{Ax}-\mathrm{Ay}) / \mathrm{Ax} \times 100]
$$

where,

Ax - absorbance of the control (blank, without extract) and

Ay - absorbance in the presence of the extract.

\section{Statistical analysis}

The data was represented as mean \pm SEM and \pm S.D for six rats. One-way analysis of variance (ANOVA) followed by Dunnett's test was performed by using Graph Pad Prism 2.01 (Graph Pad Software Inc.). The data were expressed as the mean \pm standard error of the means (SEM) and a value of $p<0.05$ was considered as statistically significant.

\section{Results}

\subsection{Body weight and food intake}

The body weight $(\mathrm{g})$ of each group once were taken before starting of feeding with high-fat diet, then after 10 days of high-fat diet feed and final body weight after dosing of test drugs at 28 days (Table 2 ). Food intake (g), food efficiency ratio and BMI were calculated at 28 days and documented in (Table 4 ). 
Table 2: Effect of $A$. sowa on body weight

\begin{tabular}{|l|l|l|l|l|}
\hline Treatment groups $(\mathbf{n}=\mathbf{6})$ & Dose $(\mathbf{m g} / \mathbf{k g}$ p.o $)$ & $\begin{array}{l}\text { Initial body weight } \\
(\mathbf{g})(\mathbf{0} \text { Day })\end{array}$ & $\begin{array}{l}\text { Body weight }(\mathrm{g}) \\
(\mathbf{1 0} \text { Day })\end{array}$ & $\begin{array}{l}\text { Final body weight } \\
(\mathbf{g})(\mathbf{2 8} \text { Day })\end{array}$ \\
\hline Normal control-I & -ve Control & $143.66 \pm 3.39$ & $145.46 \pm 2.32$ & $144.33 \pm 3.65$ \\
High fat diet (HFD)-II & +ve Control & $155.16 \pm 4.86$ & $215.13 \pm 3.56^{\# \#}$ & $284.50 \pm 2.86$ \\
HFD + Orlistat-III & 05 & $150.66 \pm 8.13$ & $208.34 \pm 4.10^{\# \#}$ & $162.50 \pm 7.54^{* *}$ \\
HFD + EASR-IV & 100 & $146.83 \pm 2.38$ & $211.33 \pm 3.35^{\# \#}$ & $186.66 \pm 3.71^{*}$ \\
HFD + EASR-V & 200 & $157.33 \pm 4.55$ & $217.65 \pm 2.74^{\# \#}$ & $166.48 \pm 4.83^{* *}$ \\
\hline
\end{tabular}

Each value is expressed in Mean \pm SEM One-way ANOVA followed by Dunnett's test.

P. ${ }^{\#} p<0.05$ and ${ }^{\#} p<0.01$ compare to normal control group.

P: $* p<0.05$ and $* * p<0.01$ compare to (HFD) positive control group.

Table 3: Effect of $A$. sowa on food intake, food efficiency ratio and BMI

\begin{tabular}{|c|c|c|c|c|c|}
\hline $\begin{array}{l}\text { Treatment groups } \\
(n=6)\end{array}$ & Dose (mg/kg p.o) & $\begin{array}{l}\text { Final weight } \\
\text { gain }(\mathrm{gm})\end{array}$ & $\begin{array}{c}\text { Final food } \\
\text { intake }\left(\mathrm{gm}^{2}\right)\end{array}$ & $\begin{array}{l}\text { FER (weight } \\
\text { gain/food } \\
\text { intake) }\end{array}$ & BMI \\
\hline Normal control-I & -ve Control & $15.67 \pm 2.45$ & $9.51 \pm 0.12$ & 1.647739 & $0.69 \pm 0.01$ \\
\hline High fat diet (HFD)-II & +ve Control & $129.34 \pm 3.78^{\# \#}$ & $17.21 \pm 0.18$ & $7.515398^{\# \#}$ & $0.9 \pm 0.016^{\# \#}$ \\
\hline HFD + Orlistat-III & 05 & $17.84 \pm 2.76 * *$ & $10.21 \pm 0.15$ & $1.747307 * *$ & $0.67 \pm 0.028 * *$ \\
\hline HFD + EASR-IV & 100 & $63.83 \pm 2.58 *$ & $14.38 \pm 0.11$ & $4.438804 *$ & $0.77 \pm 0.007 *$ \\
\hline HFD + EASR-V & 200 & $29.15 \pm 2.1 * *$ & $11.23 \pm 0.09$ & $2.595726 * *$ & $0.72 \pm 0.023 * *$ \\
\hline
\end{tabular}

Each value is expressed in Mean \pm SEM One-way ANOVA followed by Dunnett's test.

P: $\# p<0.05$ and ${ }^{\#} p<0.01$ compare to normal control group.

P: $* p<0.05$ and $* * p<0.01$ compare to (HFD) positive control group

Table 4: Effect of $A$. sowa on relative organ weight

\begin{tabular}{|l|l|c|c|}
\hline Treatment groups $(\mathbf{n}=\mathbf{6})$ & Dose $(\mathbf{m g} / \mathbf{k g}$ p.o) & Heart $(\mathbf{g})$ & Liver $(\mathrm{g})$ \\
\hline Normal control -I & -ve Control & $1.1 \pm 0.034$ & $7.96 \pm 0.036$ \\
High fat diet (HFD)-II & + ve Control & $2.49 \pm 0.117^{\# \#}$ & $10.72 \pm 0.056^{\# \#}$ \\
HFD + Orlistat-III & 05 & $1.14 \pm 0.015^{* *}$ & $2.53 \pm 0.078^{\# \#}$ \\
HFD + EASR-IV & 100 & $2.18 \pm 0.128^{*}$ & $10.19 \pm 0.08^{*}$ \\
HFD + EASR-V & 200 & $1.84 \pm 0.1 * *$ & $2.069^{* *}$ \\
\hline
\end{tabular}

Each value is expressed in Mean \pm SEM One-way ANOVA followed by Dunnett's test.

P: ${ }^{\#} p<0.05$ and ${ }^{\#} p<0.01$ compare to normal control group.

P: $* p<0.05$ and $* * p<0.01$ compare to (HFD) positive control group.

Table 5: Effect of $A$. sowa on lipid serum profile

\begin{tabular}{|c|c|c|c|c|c|c|c|}
\hline $\begin{array}{l}\text { Treatment } \\
\text { groups }(n=6)\end{array}$ & $\begin{array}{l}\text { Dose } \\
\text { (mg/kg p.o) }\end{array}$ & $\begin{array}{l}\text { VLDL } \\
\text { (mg/dl) }\end{array}$ & $\begin{array}{l}\text { HDL } \\
\text { (mg/dl) }\end{array}$ & $\begin{array}{l}\text { TC } \\
(\mathbf{m g} / \mathbf{d l})\end{array}$ & $\begin{array}{l}\text { TG } \\
(\mathbf{m g} / \mathbf{d l})\end{array}$ & $\begin{array}{l}\text { LDL } \\
\text { (mg/dl) }\end{array}$ & AI \\
\hline Normal control-I & -ve Control & $19 \pm 0.37$ & $58.7 \pm 0.87$ & $127.97 \pm 1.01$ & $95.05 \pm 1.9$ & $50.26 \pm 1.76$ & $0.209 \pm 0.009$ \\
\hline High fat diet (HFD)-II & +ve Control & $37.12 \pm 0.25^{\# \#}$ & $34.33 \pm 0.49^{\# \#}$ & $172.6 \pm 0.73^{\# \#}$ & $185.64 \pm 1.29^{\# \#}$ & $101.14 \pm 0.63^{\# \#}$ & $0.732 \pm 0.004^{\# \#}$ \\
\hline HFD + Orlistat-III & 05 & $19.13 \pm 0.4 * *$ & $54.52 \pm 0.61 * *$ & $130.39 \pm 1.09^{* *}$ & $95.68 \pm 2.03 * *$ & $56.73 \pm 0.34 * *$ & $0.243 \pm 0.009^{* *}$ \\
\hline HFD + EASR-IV & 100 & $25.37 \pm 0.3^{*}$ & $41.96 \pm 0.45^{*}$ & $153.92 \pm 0.63 *$ & $126.87 \pm 1.51^{*}$ & $86.61 \pm 0.57^{*}$ & $0.480 \pm 0.004^{*}$ \\
\hline HFD + EASR-V & 200 & $19.78 \pm 0.26^{* *}$ & $42.48 \pm 0.39 * *$ & $136.13 \pm 1.08^{* *}$ & $98.95 \pm 1.32 * *$ & $67.86 \pm 0.92 * *$ & $0.309 \pm 0.006^{* *}$ \\
\hline
\end{tabular}

Each value is expressed in Mean \pm SEM One-way ANOVA followed by Dunnett's test.

P: ${ }^{\#} p<0.05$ and ${ }^{\#} p<0.01$ compare to normal control group.

P: $* p<0.05$ and $* * p<0.01$ compare to (HFD) positive control group.

\subsection{Determination of relative organ weight}

The weight of the liver, spleen and heart were increased when animals of group II, III, IV and V feed with high-fat diet for 10 days. The weight of liver, spleen and heart were normalized significantly $(\mathrm{p}<0.05$ and $p<0.01)$ by the treatment with standard drugs Orlistat and both doses of test drug (EASR) as compared to (HFD) positive control group after 28 days (Table 4). 


\subsection{Assessment of lipid serum profile}

Table 5 showed that the concentration of TC, TG, LDL and VLDL levels significantly increase and a reduction in the HDL by HFD fed in rats compared to the normal control group I. Treatment with standard drug $5 \mathrm{mg} / \mathrm{kg}$ Orlistat of group III and EASR 100 and 200 $\mathrm{mg} / \mathrm{kg}$ of groups IV and V showed significant decrease $(p<0.05$ and $* * p<0.01)$ in TC, TG, LDL and VLDL levels and increases the concentration of HDL. The results also showed the serum AI significantly increased $(p<0.01)$ in HFD induced obese animals when compare to normal control group and tested drugs showed significantly decrease the AI level.

\subsection{Parameters for oxidative stress}

Table 6 showed the various oxidative stress markers such as SOD, GSH, GPx decreases and TBARS were significantly increased in highfat diet group II when compare with normal control group I. Treatment with standard drug $5 \mathrm{mg} / \mathrm{kg}$ Orlistat of group III and EASR 100 and $200 \mathrm{mg} / \mathrm{kg}$ of groups IV and V showed significant increase $(p<0.05$ and $* * p<0.01$ ) level of SOD, GSH, GPx decreases and TBARS.

Table 6: Effect of $A$. sowa on lipid serum profile

\begin{tabular}{|l|l|l|l|l|l|}
\hline $\begin{array}{l}\text { Treatment groups } \\
(\mathbf{n}=6)\end{array}$ & $\begin{array}{l}\text { Dose } \\
\text { (mg/kg p.o) }\end{array}$ & $\begin{array}{l}\text { SOD } \\
\text { (unit/mg tissue) }\end{array}$ & $\begin{array}{l}\text { GSH } \\
\text { (mg/g tissue) }\end{array}$ & $\begin{array}{l}\text { GPx } \\
\text { (nmol/min/mg } \\
\text { protein) }\end{array}$ & $\begin{array}{l}\text { TBARS } \\
\text { (nmol of MDA } \\
\text { formed/g tissue) }\end{array}$ \\
\hline Normal control-I & -ve Control & $40.11 \pm 0.144$ & $37.84 \pm 0.485$ & $13.25 \pm 0.411$ & $25.73 \pm 0.398$ \\
High fat diet (HFD)-II & +ve Control & $16.04 \pm 0.221^{\# \#}$ & $17.17 \pm 0.499^{\# \#}$ & $6.45 \pm 0.247^{\# \#}$ & $82.54 \pm 0.396^{\# \#}$ \\
HFD + Orlistat-III & 05 & $37.14 \pm 0.095^{* *}$ & $33.27 \pm 0.661^{* *}$ & $11.97 \pm 0.359^{* *}$ & $31.57 \pm 0.551^{* *}$ \\
HFD + EASR-IV & 100 & $23.12 \pm 0.167^{*}$ & $21.02 \pm 0.364^{*}$ & $7.96 \pm 0.353^{*}$ & $63.55 \pm 0.405^{*}$ \\
HFD + EASR-V & 200 & $31.92 \pm 0.113^{*}$ & $26 \pm 0.381^{* *}$ & $11.18 \pm 0.321^{* *}$ & $37.14 \pm 0.576^{* *}$ \\
\hline
\end{tabular}

Each value is expressed in Mean \pm SEM One-way ANOVA followed by Dunnett's test.

P: ${ }^{\#} p<0.05$ and ${ }^{\# \#} p<0.01$ compare to normal control group.

$\mathrm{P}: * p<0.05$ and $* * p<0.01$ compare to (HFD) positive control group.

\subsection{Total phenolic and flavonoidal content}

The results of phenolic and flavonoids contents of the ethanol extract of A. sowa roots (EASR) are summarized in Table 7.

Table 7: Phenolic and flavonoidal content present in A.sowa roots

\begin{tabular}{|l|l|l|}
\hline EASR & Phenolic content $*$ & Flavonoids contents $^{\#}$ \\
\hline 50 & $114.32 \pm 1.053$ & $270.23 \pm 1.137$ \\
100 & $342.25 \pm 1.062$ & $435.53 \pm 1.121$ \\
200 & $532.43 \pm 1.026$ & $609.43 \pm 1.124$ \\
\hline
\end{tabular}

All values are expressed as mean $\pm \mathrm{SD}(\mathrm{n}=3)$.

$* \mu \mathrm{g}$ of gallic acid equivalent per 50,100 and $200 \mathrm{mg}$ of extract.

${ }^{\#} \mu \mathrm{g}$ of rutin equivalent per 50,100 and $200 \mathrm{mg}$ of extract.

4.6 DPPH scavenging activity

The ethanol extract of $A$. sowa roots was compared with ascorbic acid for DPPH radical scavenging activity. The DPPH \% inhibition activity of $A$. sowa roots extract was $43.94 \%$ at $100 \mu \mathrm{g} / \mathrm{ml}$, respectively (Figure 1). It was observed that the \% inhibition (at $15 \mathrm{~min}$ ) with the $\mathrm{IC}_{50}$ values of the ethanol extract of $A$. sowa roots (EASR) was found to be $97.5 \mu \mathrm{g} / \mathrm{ml}$ compared to standard ascorbic acids $68.74 \mu \mathrm{g} / \mathrm{ml}$.

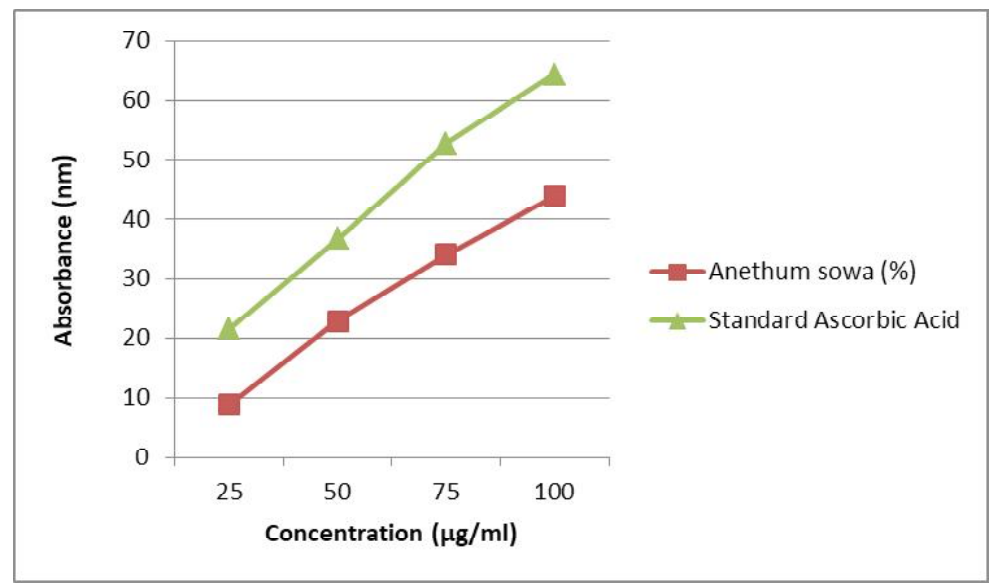

Figure 1: DPPH scavenging activity. 


\section{Discussion}

Preliminary phytochemical screening of the ethanol extract of A. sowa roots (EASR) revealed the presence of reducing sugar, phenolics, flavonoids, terpenoids and steroids as major phytoconstituents. Hence, the presence of phenolics, flavonoids and terpenoids in EASR were responsible for the antioxidant and antiobesity potential of $A$. sowa roots. The HFD induced model comprises of high calorie value and high fat content, which was fed to rats to induce obesity (Kumar et al., 2011). As per the various studies conducted rats fed with high-fat diet are exceptional model of obesity where dietary conditions can be compared with the dietary obesity that occurs in humans (Duca et al., 2012; Bull, 1988). In the HFD model, the physical parameters such as body weight, food intake, food efficiency ratio, BMI and the biochemical parameters such as AI, TC, TG, HDL, LDL and VLDL levels were determined (Kwon et al., 2003). On feeding, the rats with HFD diet the body weight escalated to a great extent due to the deposition of fat in the body and the drug, A. sowa showed its protective nature in rats by averting their weight gain. The weight of organs like liver was remarkably increased due to the deposition of fat all over the organ and the drug, A. sowa averted the increase in weights of the organs in rats. One of the predominant changes that occur in obese people is their biochemical parameters which are lipid serum profile. During obesity, the levels of TC, TG, LDL and VLDL elevates whereas HDL also known as good cholesterol decreases. Increase in the levels of TC, TG and LDL are crucial risk factors which are responsible the evolution of cardiovascular disorders such as hypertension, coronary heart disease, hyper lipidaemia, atherosclerosis, etc.

The increased level of TC and TG due to the feeding of HFD diet is transported to the tissues through blood. The rats getting the drug A. sowa did not have increased TC, TG, LDL and VLDL levels as compared to HFD fed rats. Also, the levels of oxidative stress markers such as SOD, GSH, GPx and TBARS in rats receiving the drug, $A$. sowa were significantly increased. The $\operatorname{drug} A$. sowa protected the rats by intercepting the changes in physical parameters, lipid profile and oxidative stress markers. The free radical scavenging capacity of EASR was investigated by DPPH. DPPH activity of antioxidants is due to the donating capability of hydrogen. The results from the DPPH assay revealed that the EASR showed an efficient quenching of DPPH radicals, and thus contain free radical quenching compounds, which act as primary radical and, scavengers that react with DPPH (Kamal et al., 2019).

\section{Conclusion}

The research concentrated on the estimation of in vivo antiobesity effects of ethanol extract of $A$. sowa roots (EASR) in high-fat diet induced obese female SD rats. The outcome stipulated that $A$. sowa revealed antiobesity effects through the depletion in body weight, food intake, food efficiency ratio, BMI and relative organ weights. Apart from that, a reduction in levels of atherogenic index (AI), serum triglycerides, total cholesterol, LDL-C, VLDL and an increase in HDL-C alongwith oxidative stress markers are evocative that $A$. sowa roots extracts have antiobesity potential.

\section{Acknowledgments}

The authors express their gratitude toward Hon. Chancellor, Professor Syed Waseem Akhtar, Integral University and Vice
Chancellor, Professor Javed Musarrat, Integral University for providing research environment and all necessary facilities for conducting research. The University has provided a communication number for further internal communication (IU/R\&D/2021MCN0001275).

\section{Author contribution}

All the authors have accepted responsibility for the entire content of manuscript of this submitted manuscript and contributed equally.

\section{Conflict of interest}

The authors declare no conflicts of interest relevant to this article.

\section{References}

Arif, M. and Fareed, S. (2010). Pharmacognostic investigation and authentication of potentially utilized fruit Spondias mangifera (Willd). Int. J. Curr. Pharmaceut. Clin. Res., 2(1):31-35.

Blumenthal, M.; Goldberg, A. and Brinckmann, J. (2000). Herbal medicine: expanded commission E monographs. MA Newton. Integr. Med. Comm., pp:78-83.

Bull, N.L. (1988). Studies of dietary habits, food consumption and nutrient intake of adolescents and young adults. World Rev. Nutr. Diet., 57:24-34.

Chahal, K.K.; Monika, Kumar.A.; B hardwaj, U. and Kaur, R. (2017). Chemistry and biological activities of Anethum graveolens L. (dill) essential oil: A review. J. Pharmacogn. Phytochem., 6(2):295-306.

Cordatos, E.; Murray, M. and Pizzorno, J. (1992). A textbook of natural medicine. Bastyr. Univ. Press, 4(2):112-114.

Duca, F.A.; Swartz, T.D.; Sakar, Y. and Covasa, M. (2012). Decreased intestinal nutrient response in diet induced obese rats: Role of gut peptides and nutrient receptors. Int. J. Obes., 4:21-24.

Friedewald, W.T.; Levy, R.I. and Fredrickson, D.S. (1972). Estimation of the concentration of low-density lipoprotein cholesterol in plasma, without use of the preparative ultracentrifuge. Clin. Chem., 18: 499-502.

Gezici, S.; Koçum, D.; Yayla, F.; Sekeroglu, N. and Khan, A.A. (2020). Screening for in vitro antioxidant activities, polyphenolic contents and neuroprotective potenti also Clinopodium serpyllifolium subsp. Serpyllifolium endemic to Turkey. Ann. Phytomed., 9(1):181186.

Giampiero, Muccioli., Tschop, Matthias., Papotti, Mauro., Deghenghi, Romanco. and Heiman, Mark (2002). Neuroendocrine and peripheral activities of ghrelin implications in metabolism and obesity, Eur. J. Pharmacol., 440(2-3):235-254.

Iqbal, Noushina., Umar, Shahid., Tasir, S. and Khan, Nafees. A. (2017). Ethephon increases photosynthetic-nitrogen use efficiency, proline and antioxidant metabolism to alleviate decrease in photosynthesis under salinity stress in mustard. Plant Signal. Behav., 12(5):10-15.

Jaishree, V.; Badami, S. and Krishnamurthy, P.T. (2010). Antioxidant effect and hepatoprotective effect of ethyl acetate extract of Enicostemma axillare (Lam) Raynal against $\mathrm{CCl} 4$ induced liver injury in rats. Indian J. Exp. Bio., 48:896-904.

Janardanan, Mohandas.; Jocelyn, J. Marshall.; Geoffrey, G. Duggin.; John, S. Horvath. and David, J. Tiller. (1984). Low Activities of Glutathionerelated Enzymes as Factors in the Genesis of Urinary Bladder Cancer. Can. Res., 44:5086-5091. 
Kamal, M.; Naz, M.; Jawaid, T. and Arif, M. (2019). Natural products and their active principles used in the treatment of neurodegenerative diseases: a review. Oriental Pharmacy and Experimental Medicine, 19(4):343-365.

Kaur, G. and Kulkarni, S.K. (2000). Antiobesity effect of a polyherba formulation, OB $200 \mathrm{~g}$ in female rats fed on cafeteria and atherogenic diets. Indian J. Pharmacol., 32:294-309.

Kumar, R.S.; Lakshmi, P.T.V. and Annamalai, A. (2009). Effect of drying treatment on the content of antioxidants in Enicostem malittorale Blume. Res. J. Med. Plant, 3:93-101.

Kumar, S.; Alagawadi, K.R. and Rao, M.R. (2011). Effect of Argyreia speciosa root extract on cafeteria diet induced obesity in rats. Indian $\mathrm{J}$. Pharmacol., 43:163-177.

Kwon, C.S.; Sohn, H.Y.; Kim, S.H.; Kim, J.H.; Son, K.H. and Lee, J.S. (2003). Ant obesity effect of Dioscorea nipponica Makino with lipase inhibitory activity in rodents. Bio. Sci. Biotechnol. Biochem., 67:1451-1466.

Modi, C.M.; Ladumor, V.C.; Patel, U.D.; Patel, H.B.; Solanki, S.L. and Bhadarka, D.H. (2018). Phytochemical analysis and comparative study of in vitro free radical scavenging activity of different extracts of leaves of Abrus precatorius L. Ann. Phytomed., 7(2):133-137.

Muhammad, A. and Sheeba, F., (2011). Pharmacognostical and preliminary phytochemical analysis of Carissa carandas fruits. Journal of Medicinal and Aromatic Plant Sciences, 33(1):53-58.

Nwagha, U.I.; Ikekpeazu, E.J. and Ejezie, F.E.(2010). Atherogenic index of plasma as useful predictor of cardiovascular risk among post menopausal women in Enugu, Nigeria. Afr. Health Sci., 10:248252

Ordonez, A.A.L.; Gomez, J.D., Vattuone, M.A. and Isla, M.I. (2006). Antioxidant activities of sechiumedule (Jacq.) swart extracts. Food Chem., 97:452-458

Qadir,A.; Aqil, M.; Ali, A.; Ahmad, F.J.; Ahmad, S., Arif, M. and Khan, N. (2020). GC-MS analysis of the methanolic extracts of Smilax china and
Salix alba and their antioxidant activity. Turkish Journal of Chemistry, 44(2), pp.352-363.

Randhwa, G.S., Kaur, S., Chadha, K.L. and Gupta, R. (1995). Dill: Medicinal and aromatic plants. Malhotra Publication House, Delhi.

Sachan, N.K., Arif, M., Zaman, K. and Kumar, Y. (2011). Anti-inflammatory, analgesic and antioxidant potential of the stem bark of Spondias mangifera Willd. Archives of Biological Sciences, 63(2), pp.413419.

Singh, M.P. and Panda, H. (2005). Medicinal herbs with their formulations. Daya Publishing House, Delhi, India.

Srinivasan, K., Viswanad, B., Asrat, L., Kaul, C.L. and Ramarao, P. (2005). Combination of high-fat diet-fed and low-dose streptozotocintreated rat: A model for type 2 diabetes and pharmacological screening. Pharmacological Research, 52(4):313-320.

Suresha B.S. (2004). Investigation of the antiobesity activity of poly herbal formulation in rats, Visveswarapura Institute of Pharmaceutical Sciences, Bangalore, Karnataka, India, 4.

Vani, M.L. and Reddy, K.P. (2000). Effects of fluoride accumulation on some enzymes of brain and Gastrocnemius muscle of mice. Int. Society of Fluoride Res., 33:17-26.

Vijaya,T., Latha, B.Pushpa., Reddy, I. Rama Manohar., Ismail, M. and Rao, S. Dattatreya (2011). Therapeutic efficacy of Achyranthesa sperasaponin extract in high fat diet induced hyperlipidaemia in male wistar rats African Journal of Biotechnology, 10(74):1703817042 .

Wali, A.F.; Hamad, E.A.; Khazandar, A.A.; Al-Azzawi, A.M.; Sarheed, O.A.; Menezes, G.A. and Alam, A. (2019). Antimicrobial and in vitro antioxidant activity of Salvia officinalis L. against various re-emergent multidrug resistance microbial pathogens. Ann. Phytomed., 8(2):115-120.

Wichtl, M. (1994). Herbal drugs and phytopharmaceuticals. Boca Raton. FL: CRC Press, pp:486-489. 